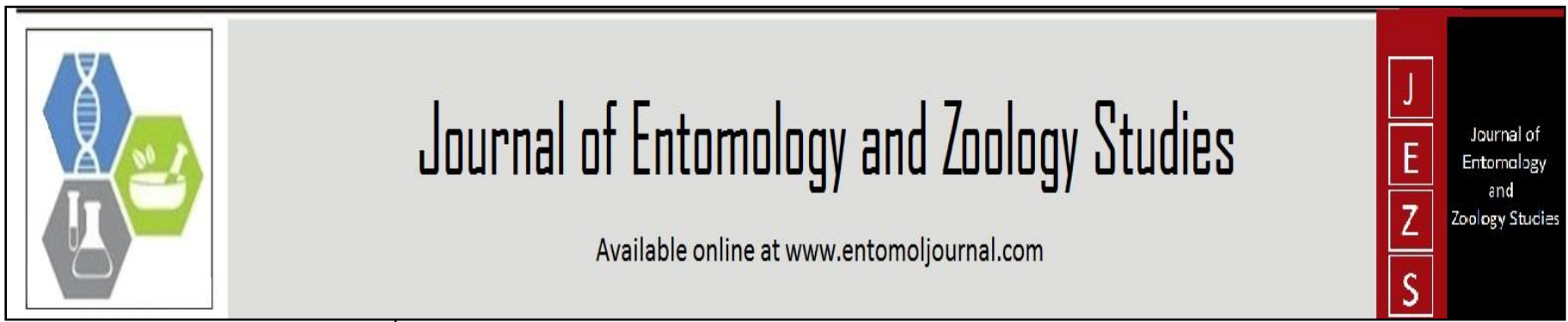

E-ISSN: 2320-7078

P-ISSN: 2349-6800

www.entomoljournal.com

JEZS 2020; 8(6): 147-152

(C) $2020 \mathrm{JEZS}$

Received: 21-09-2020

Accepted: 27-10-2020

\section{Nermin Öztekin}

Department of Plant Protection

Faculty of Agriculture, Harran

University, Şanlıurfa, Turkey

\section{Cetin Mutlu}

Department of Plant Protection Faculty of Agriculture, Harran

University, Şanlıurfa, Turkey

\section{Corresponding Author:}

\section{Çetin Mutlu}

Department of Plant Protection

Faculty of Agriculture, Harran

University, Şanlıurfa, Turkey

\section{Efficacy of three diatomaceous earth formulations against cowpea beetle, Callosobruchus maculatus (F.) (Coleoptera: Bruchidae), on bean}

\section{Nermin Öztekin and Çetin Mutlu}

DOI: https://doi.org/10.22271/j.ento.2020.v8.i6b.7848

\section{Abstract}

Laboratory experiments were carried out to evaluate the effect of three diatomaceous earth (DE) formulations (two local Aydın and Ankara) and Silicosec ${ }^{\circledR}$ (Biofa, Germany) against Callosobruchus maculatus (F.) (Coleoptera: Bruchidae) adults on bean at 25 and $30^{\circ} \mathrm{C}$. DEs were treated with three doses $(200,400$ and $600 \mathrm{mg} / \mathrm{kg}$ ) and control. The adult mortality was assessed after 2, 3, 5, 7, 14 and 21. day of application (DAT). The highest mortality rate $(100 \%)$ on the cowpea beetle was recorded for Ankara DE on 5. DAT at $25{ }^{\circ} \mathrm{C}$ with $600 \mathrm{ppm}$, followed by Aydin and SilicoSec ${ }^{\circledR} \mathrm{DE}(84.97 \%$ and $63.47 \%)$. The biological activity of local DE increased with increasing application dose, exposure time and temperature. The highest mortality at $30{ }^{\circ} \mathrm{C}$ was determined for SilicoSec $®(100 \%)$ with $600 \mathrm{ppm}$ on 2. DAT followed by Ankara and Aydin (94.95 and 94.59\% respectively). After 3 DAT, 600 ppm dose showed the highest efficacy all three DEs. There was no new generation emergence of all DEs treatment. It was concluded that the local DEs (Ankara and Aydin) have a high potential to be used for control of $C$. maculatus adults damage for storage bean.

Keywords: Diatomaceous earth, Callosobruchus maculatus, efficacy, mortality, stored pulse

\section{Introduction}

The cowpea beetle, [Callosobruchus maculatus (F.) (Coleoptera: Bruchidae)], is bean bruchid, widely distributed throughout the world as well as Turkey [36, 3, 42, 22]. The pest is very destructive stored pest of legumes such as cowpea, chickpea, lentil, soybean, bean ${ }^{[3,31,22]}$. The adult beetle infestation may start in the pods before harvest and carry over into storage where substantial losses may occur ${ }^{[10]}$. The larvae bore into the seed and feed within the same seeds and damage in terms of holes produced by adult emergence from stored seeds can increase to $100 \%$ after $3-5$ months of ordinary storage conditions ${ }^{[23]}$. Thus, they cause huge quantitative and qualitative losses in legume seeds ${ }^{[11,36]}$. Some control measures need to be application in order to minimize the losses caused by this pest. Most attempts to control this pest relied on synthetic insecticides. The ubiquitous issues of pesticide residue and pest resistance to pesticides are becoming increasingly challenging for society to solve ${ }^{[25,32]}$. Insecticides are mainly used for its control and recently some plants essential oil were also used in Turkey ${ }^{[12,}$ 40,22]. Therefore, there is an increased need for alternative plant protection materials against the cowpea beetle ${ }^{[25]}$. Besides, several alternatives control methods (natural products such as, palm oil, tobacco extract, leaf essential oils, seed extracts and inert dusts) have been studied against stored pests including $C$. maculatus. ${ }^{[20,29,34,42,14]}$.

Dusts, such as diatomaceous earth (DE), are known insecticidal or repellant activity products and effectively controls most species of insect pests of stored products ${ }^{[15,43]}$. Diatomaceous earth is a naturally occurring, soft, siliceous sedimentary rock and consists of fossilized skeletons of freshwater or marine of diatoms ${ }^{[29]}$. Diatomaceous earth acts larvae and on adults, stick to insect's body parts as they move on their surface or inside the treated grain mass [26, 39, 42,43 . When it contacts with insects, it causes the removal of the layer of wax from insect cuticle, bringing about their death by desiccation ${ }^{[39]}$. Besides, this product is extremely stable and has low toxic effect on mammalian, little potential for insect resistance as well as a good residual effect ${ }^{[16,15,29]}$. Turkey has a huge and good quality diatomaceous earth reserve (125 million tons) and most of them geological deposits occur in some regions (especially Center Anatolia, Aegean region) of Turkey ${ }^{[13]}$. With the diatomaceous earths from regional deposits as grain protectant in farm stores of Turkey, their potential low costs, readily availability and 
easiness to use, many farmers and grain dealers can use them as grain protectant. Although there are very abundant and high-quality diatomite reserves in Turkey, they cannot be evaluated adequately of these reserves for controlling stored products pest. DE formulations with dry grains are an excellent method of protecting the commodity against stored product pest ${ }^{[36]}$.

Although there are many studies evaluating insecticidal, biological and repellent activity of local and registered DEs against some stored product pests $[29,30,18,7,43,14,17,50,2,41,27]$, but there is no information on the efficacy of local DEs formulation against $C$. maculatus on bean in Turkey. The main objective of the study was to determine efficacy of two local diatomaceous earth (Aydin and Ankara) and SlicoSec on mortality of DE-treated the cowpea beetle on bean at the laboratory-controlled conditions in 2020.

\section{Materials and Methods}

\subsection{Diatomaceous Earth (DE) formulations}

Three diatomaceous earth (two native diatomaceous earth, Ankara, Aydın provinces and SilicoSec ${ }^{\circledR}$ ) were used in the study. The DE formulations are given in Table 1.

Table 1: The formulations of diatomaceous earths used in the study

\begin{tabular}{|c|c|c|c|c|c|c|}
\hline DE$^{*}$ & $\begin{array}{c}\mathrm{SiO}_{\mathbf{2}} \\
(\%)\end{array}$ & $\mathbf{A l}_{2} \mathbf{O}_{3}$ & $\mathrm{Fe}_{2} \mathrm{O}_{3}$ & $\mathrm{CaO}_{\mathbf{N a}} \mathbf{O}$ & $\begin{array}{c}\text { Particle } \\
\text { diameter size }\end{array}$ \\
\hline Ankara & 92.8 & 4.2 & 1.5 & 0.3 & - & $8-12 \mu$ \\
\hline Aydın & 94.2 & 4.6 & 1.6 & 0.3 & - & $8-12 \mu$ \\
\hline SilicoSec $^{(* * * *}$ & 92.0 & 3 & 1 & - & 1 & $8-12 \mu$ \\
\hline
\end{tabular}

*DE: Diatomaceous earth

**A sample of dry formulation of Silicosec ${ }^{\circledR}$ was obtained from Biofa GmbH, Germany

\subsection{Test insects}

Callosobruchus maculatus adults were obtained from the cultures maintained at Entomology Laboratory, Plant Protection Central Research Institute Ankara, Turkey. The adults were reared in sterile 1-L transparent plastic jars on chickpea in incubators at $30 \pm 1^{\circ} \mathrm{C}$ temperature, $50-65 \pm 5 \%$ relative humidity and 16:8 $\mathrm{h}$ (L:D) in the insectarium of Department of Plant Protection, Faculty of Agriculture, Harran University, Turkey. Chickpea grains were kept in deep freezer at $-18{ }^{\circ} \mathrm{C}$ at least 7 days to prevent contamination. Approximately, 200-250 mixed-sex adults were released in the jars. The adults were vacuumed after 24 hours to obtain 1 day-old new adults later. The adult emergence was observed at $35-40$ days. Emerged adults were collected with an aspirator and used in experiments when they were 1 to 3 days old.

\subsection{Laboratory bioassay}

Bioassay studies were conducted according to randomized parcel design with four replicates at two temperatures (25 and $30 \pm 1^{\circ} \mathrm{C}$ ), 50-65\% RH and 16:8 h (L:D). Three doses of local (Ankara and Aydin) and SilicoSec ${ }^{\circledR}$ DEs formulation (200, 400 and $600 \mathrm{ppm}$ (mg DE/kg bean) were used. Untreated bean grains (control group) was considered as the control. For each dose, $200 \mathrm{~g}$ bean grains were used in 1-liter volume plastic jars. The jars were sealed and shaken manually for 1 min to distribute DEs on-bean grains. Thirty $C$. maculatus adults were introduced in each jar and the insects were kept in controlled condition insectarium rooms at 25 and $30 \pm 1^{\circ} \mathrm{C}$. The numbers of living and dead adults were recorded after 2 , $3,5,7,14$ and 21 days respectively.

\subsection{Effect of Diatomaceous earth on F1 progeny}

The dead and living adults were removed 21 days after the initiation of laboratory bioassay. Infested bean grains were kept at 25 and $30 \pm 1{ }^{\circ} \mathrm{C}$ and $65 \pm 5 \%$ relative humidity condition to allow oviposited eggs for hatching and development. Then newly emerged adults were counted. Inhibition rate was calculated according to the formula given below.

$\mathrm{IR} \%=(\mathrm{Cn}-\mathrm{Tn}) / \mathrm{Cn} \times 100$

IR $\%$ = inhibition rate, $\mathrm{Cn}=$ number of newly emerged insects in the untreated (control) jar, Tn = number of newly emerged insects in the treated jar.

\subsection{Statistical Analysis}

The collected data were converted into percent mortality and subjected to arcsine transformation followed by correction of cumulative mortality percentage (Abbott, 1925). Analysis of variance was conducted to assess the effect of concentration, exposure time and their interaction. The differences among treatment means were analyzed by means of Tukey's multiple comparison tests $(p<0.01)$. All statistical analyses were conducted on Jump (Version 7) package program.

\section{Results}

The mortality varied within DEs and their doses. The highest mortality was recorded at higher DEs dose $(600 \mathrm{ppm} / 100 \mathrm{~g}$ bean grains) at 25 and $30^{\circ} \mathrm{C}$, while minimum mortality was obtained with lower dose. The lowest mortality after $2^{\text {nd }}$ day was $11.72,3.39$ and $7.50 \%$ with 200 ppm dose of Ankara, Aydın and SilicoSec ${ }^{\circledR}$ DEs, respectively at $25^{\circ} \mathrm{C}$ (Table 2).

Table 2: Efficacy of different doses of three diatomaceous earth against Callosobruchus maculatus adults at $25^{\circ} \mathrm{C}$

\begin{tabular}{|c|c|c|c|c|c|c|c|}
\hline \multicolumn{8}{|c|}{ Mortality (\%) } \\
\hline DE & Doses & 2. D & 3. DAT & 5. DAT & $\mathbf{D} A$ & 14. D & 21. DA 1 \\
\hline Ankara & Control & $1.66 \mathrm{a}^{*}$ & $1.66 \mathrm{a}$ & $12.50 \mathrm{a}$ & $28.33 \mathrm{a}$ & $61.66 \mathrm{a}$ & $85.00 \mathrm{a}$ \\
\hline Ankara & $200 \mathrm{ppm}$ & $11.72 \mathrm{a}$ & $22.61 \mathrm{ab}$ & $39.27 \mathrm{~b}$ & $56.70 \mathrm{~b}$ & $61.29 \mathrm{a}$ & $93.75 \mathrm{a}$ \\
\hline Ankara & $400 \mathrm{ppm}$ & $11.72 \mathrm{a}$ & $42.61 \mathrm{~b}$ & $68.64 c$ & $83.56 \mathrm{c}$ & $92.89 b$ & $100.00 \mathrm{a}$ \\
\hline Ankara & $600 \mathrm{ppm}$ & $83.03 \mathrm{~b}$ & $93.27 \mathrm{c}$ & $100.00 \mathrm{~d}$ & $100.00 \mathrm{c}$ & $100.00 \mathrm{~b}$ & $100.00 \mathrm{a}$ \\
\hline \multicolumn{8}{|c|}{ Mortality (\%) } \\
\hline Aydın & Control & $0.83 a$ & $2.50 \mathrm{a}$ & $10.83 \mathrm{a}$ & $19.16 \mathrm{a}$ & $42.50 \mathrm{a}$ & $60.00 \mathrm{a}$ \\
\hline Aydın & $200 \mathrm{ppm}$ & $3.39 \mathrm{a}$ & $12.94 \mathrm{ab}$ & $26.20 \mathrm{a}$ & $64.80 \mathrm{~b}$ & $92.24 b$ & $100.00 \mathrm{~b}$ \\
\hline Aydın & $400 \mathrm{ppm}$ & $12.58 \mathrm{a}$ & $29.81 b$ & $63.12 b$ & $91.44 \mathrm{c}$ & $98.80 \mathrm{~b}$ & $100.00 \mathrm{~b}$ \\
\hline Aydın & $600 \mathrm{ppm}$ & $30.11 \mathrm{~b}$ & $70.04 \mathrm{c}$ & $84.97 \mathrm{~b}$ & $99.00 \mathrm{c}$ & $100.00 \mathrm{~b}$ & $100.00 \mathrm{~b}$ \\
\hline \multicolumn{8}{|c|}{ Mortality (\%) } \\
\hline 10 & Con & $2.50 \mathrm{a}$ & $9.16 \mathrm{a}$ & $24.16 \mathrm{a}$ & $32.66 \mathrm{a}$ & $52.50 \mathrm{a}$ & $95.83 \mathrm{a}$ \\
\hline
\end{tabular}

\begin{tabular}{|l|l|l|l|l|l|l|}
\hline SlicoSec 200 ppm & $7.50 \mathrm{a}$ & $16.90 \mathrm{~b}$ & $28.27 \mathrm{ab}$ & $72.84 \mathrm{~b}$ & $94.48 \mathrm{~b}$ & $100.00 \mathrm{~b}$ \\
\hline
\end{tabular}

\begin{tabular}{|l|l|l|l|l|l|}
\hline SlicoSec 400 ppm & $14.16 \mathrm{a}$ & $20.89 \mathrm{~b}$ & $53.19 \mathrm{bc} 89.90 \mathrm{bc}$ & $100.00 \mathrm{~b}$ & $100.00 \mathrm{~b}$ \\
\hline
\end{tabular}

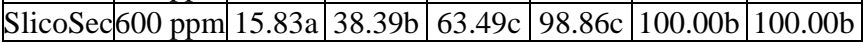

*Different letters in the same column indicate statistically different from each other $(P<0.05)$

DAT: Day after treatment

The mortality increased with increased exposure time $(3,5,7$, 14, 21 days). The 200ppm dose of all DEs was insufficient, mortality increased significantly 5 days after treatment (DAT) with $600 \mathrm{ppm}$ and reached $100 \%$ with Ankara DE. The efficacy of Aydin and SilicoSec ${ }^{\circledR}$ DEs were similar to Ankara $\mathrm{DE}$ and, $600 \mathrm{ppm}$ dose of Aydın and SilicoSec ${ }^{\circledR}$ DEs exhibited high mortality (99.00 and $98.86 \%$ respectively) at $7^{\text {th }}$ day. Insecticidal activity was $>90 \%$ with 600 ppm; however, $100 \%$ mortality was recorded with $600 \mathrm{ppm}$ dose of all three DEs at 14 DAT. The mortality rate at 21 DAT was $100 \%$ with 400 and 600 ppm doses of all DEs. The mortality 
with 400 and $600 \mathrm{ppm}$ doses of all DEs at $25{ }^{\circ} \mathrm{C}$ was substantially greater than control at 5 DAT. A considerable increase in mortality was observed with increasing duration in control treatment but remained the lowest.

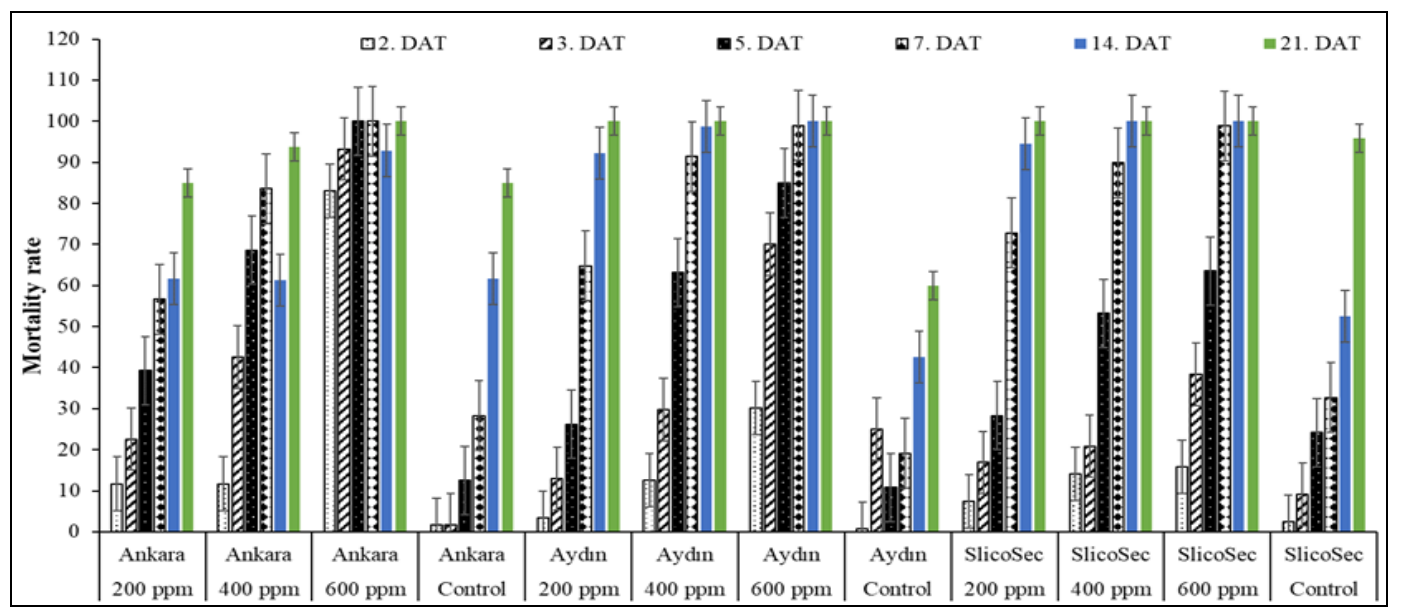

Fig. 1: The mortality rate of three DE on Callosobruchus maculatus at $25^{\circ} \mathrm{C}$

The mortality at 2, 3, 5, 7, 14 and 21 DAT with different concentrations of Ankara, Aydin and SilicoSec ${ }^{\circledR}$ DEs at $30{ }^{\circ} \mathrm{C}$ has been shown in Table 3.

Table 3: Efficacy of different doses of three diatomaceous earth against Callosobruchus maculatus adults at $30{ }^{\circ} \mathrm{C}$

\begin{tabular}{|c|c|c|c|c|c|c|c|}
\hline \multicolumn{9}{|c|}{ Mortality (\%) } \\
\hline DE & Doses & 2. DAT & 3. DAT & 5. DAT & 7. DAT & 14. DAT & 21. DAT \\
\hline Ankara & Control & $0.83 \mathrm{a}$ & $15.00 \mathrm{a}$ & $42.49 \mathrm{a}$ & $50.83 \mathrm{a}$ & $69.42 \mathrm{a}$ & $91.66 \mathrm{a}$ \\
\hline Ankara & $200 \mathrm{ppm}$ & $62.71 \mathrm{~b}$ & $83.92 \mathrm{~b}$ & $100.00 \mathrm{~b}$ & $100.00 \mathrm{~b}$ & $100.00 \mathrm{~b}$ & $100.00 \mathrm{~b}$ \\
\hline Ankara & $400 \mathrm{ppm}$ & $85.89 \mathrm{c}$ & $97.72 \mathrm{bc}$ & $100.00 \mathrm{~b}$ & $100.00 \mathrm{~b}$ & $100.00 \mathrm{~b}$ & $100.00 \mathrm{~b}$ \\
\hline Ankara & $600 \mathrm{ppm}$ & $94.95 \mathrm{c}$ & $100.00 \mathrm{c}$ & $100.00 \mathrm{~b}$ & $100.00 \mathrm{~b}$ & $100.00 \mathrm{~b}$ & $100.00 \mathrm{~b}$ \\
\hline Aydın & Control & $0.00 \mathrm{a}$ & $17.50 \mathrm{a}$ & $30.83 \mathrm{a}$ & $56.75 \mathrm{a}$ & $68.33 \mathrm{a}$ & $91.66 \mathrm{a}$ \\
\hline Aydın & $200 \mathrm{ppm}$ & $62.71 \mathrm{~b}$ & $83.92 \mathrm{~b}$ & $100.00 \mathrm{~b}$ & $100.00 \mathrm{~b}$ & $100.00 \mathrm{~b}$ & $100.00 \mathrm{~b}$ \\
\hline Aydın & $400 \mathrm{ppm}$ & $85.89 \mathrm{c}$ & $97.72 \mathrm{c}$ & $100.00 \mathrm{~b}$ & $100.00 \mathrm{~b}$ & $100.00 \mathrm{~b}$ & $100.00 \mathrm{~b}$ \\
\hline Aydın & $600 \mathrm{ppm}$ & $94.59 \mathrm{c}$ & $100.00 \mathrm{c}$ & $100.00 \mathrm{~b}$ & $100.00 \mathrm{~b}$ & $100.00 \mathrm{~b}$ & $100.00 \mathrm{~b}$ \\
\hline SlicoSec & Control & $0.00 \mathrm{a}$ & $10.83 \mathrm{a}$ & $17.50 \mathrm{a}$ & $36.66 \mathrm{a}$ & $51.66 \mathrm{a}$ & $92.50 \mathrm{a}$ \\
\hline SlicoSec & $200 \mathrm{ppm}$ & $71.16 \mathrm{~b}$ & $75.68 \mathrm{~b}$ & $100.00 \mathrm{~b}$ & $100.00 \mathrm{~b}$ & $100.00 \mathrm{~b}$ & $100.00 \mathrm{~b}$ \\
\hline SlicoSec & $400 \mathrm{ppm}$ & $92.07 \mathrm{c}$ & $100.00 \mathrm{~b}$ & $100.00 \mathrm{~b}$ & $100.00 \mathrm{~b}$ & $100.00 \mathrm{~b}$ & $100.00 \mathrm{~b}$ \\
\hline SlicoSec & $600 \mathrm{ppm}$ & $100.00 \mathrm{c}$ & $100.00 \mathrm{~b}$ & $100.00 \mathrm{~b}$ & $100.00 \mathrm{~b}$ & $100.00 \mathrm{~b}$ & $100.00 \mathrm{~b}$ \\
\hline
\end{tabular}

*Different letters in the same column indicate statistically different from each other $(P<0.05)$

DAT: Day after treatment

Exposure time to different DEs had significant effect $(P<$ 0.01 ) on mortality of the cowpea beetle at $30{ }^{\circ} \mathrm{C}$ (Table 3 ). Increasing DEs doses and exposure time resulted in increased high mortality. The mortality after $48 \mathrm{~h}$ was 94.95 and 94.59\% for Ankara and Aydın DEs respectively with 600 ppm dose. SilicoSec ${ }^{\circledR}$ caused the highest mortality (100\%) with same exposure time. The highest mortality (100\%) was recorded with $600 \mathrm{ppm}$ concentration of Ankara and Aydın DEs on $3^{\text {th }}$ DAT. After 5 DAT, $100 \%$ mortality was recorded at three DEs with $200 \mathrm{pmm}$. Mortality rate in the untreated control group increased as exposure time was extended.

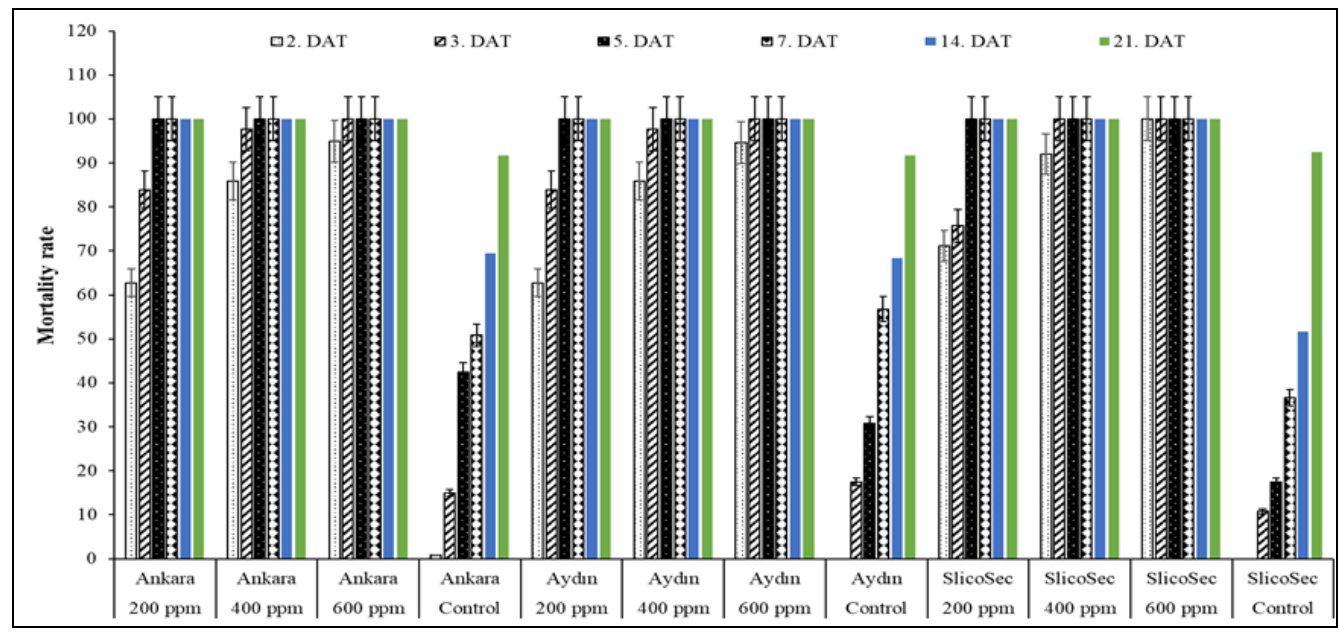

Fig. 2: The mortality rate of three DE on Callosobruchus maculatus at $30{ }^{\circ} \mathrm{C}$ 149 
There was no F1 adult emergence all DEs, doses and DAT at two temperatures, after the long storage period (60 days).

\section{Discussion}

This study investigated the effects of three diatomaceous earths (DEs) (two local-Aydin and Ankara) on mortality of cowpea beetle adults under controlled conditions. The results indicated that the efficacy of all DEs was considerably influenced by application doses, exposure time, temperature and DEs formulations. Several factors, including dose, temperature and exposure time influence the efficacy of DEs. Similar results have been reported by previous researchers ${ }^{[29}$, $5,4,33,35,9,2,41,27]$. These studies indicated increased mortality of stored product pests exposed to inert dusts with increasing exposure time. Exposure time of 2 days of DEs was enough to obtain significant mortality with tested DEs in the current study. However, mortality increased with increased exposure time from 5 DAT and reached to the highest on 14 DAT at 25 and the highest mortality reached on 3 DAT at $30^{\circ} \mathrm{C}$. Similar results have been reported by Parasantha et al., (2002); Parsaeyan et al., (2012); Badii et al., (2014), Kabir and Wulgo (2014) [35, 9, 25] who stated that mortality of $C$. maculatus increased with increasing exposure interval and temperature. Prolonged exposure time may be needed to increase mortality in adults because more dust particles are trapped by insect bodies with increasing exposure time and in turn insects lose more water and died of desiccation ${ }^{[19,5,38,42]}$. The efficacy of DEs increased with higher doses and temperature. This effect shows that the mortality of insects is dependent on the conditions in which the grains are exposed to DEs ${ }^{[43]}$. The particles of DEs have abrasive peculiarities and have ability to absorb lipid molecules from the cuticle of the insects leading to water loss, dehydration and mortality [37, 29, 45]. Although particle size of all DEs was similar, SilicoSec ${ }^{\circledR}$ had moderate effect on cowpea beetle adults and the mortality increased after 5 DAT for SlicoSec ${ }^{\circledR}$. These results indicate that DEs from different origins vary in their efficacy against maize weevil. This has also been explained by Korunic (1997) and (Golob, 1997) ${ }^{[28,21] .}$

The mortality was considerably increased with increasing temperature and was higher at $30^{\circ} \mathrm{C}$ than $25^{\circ} \mathrm{C}$. The earlier studies on the influence of temperature on the efficacy of some local and traded DEs against stored pest ( $S$. oryzae, $T$. confusum and $R$. dominica) showed that increasing temperature resulted in increased insecticidal efficiency against $S$. oryzae [19, 6, 8, 48, 39,41]. The results of the current study agree with Vassilakos et al., (2006) who reported that insecticidal efficacy of SilisoSec ${ }^{\circledR}$ against $S$. oryzae increased with increasing temperature. However, increased temperature would also increases feeding and moisture replacement through production of metabolic water. The synthesis of cuticular waxes may be faster at higher temperatures because of temperature effects on the biochemical pathways ${ }^{[46,41]}$. High temperatures stimulate the movement of insects within the grain mass, allowing them greater contact with the DEs. In addition, water loss is likely to be increased at higher temperatures ${ }^{[19,5]}$.

The total mortality was influenced by DE types under both temperatures. The local DEs, Ankara and Aydin, showed $>90 \%$ mortality 5 DAT, while SilicoSec ${ }^{\circledR}$ caused $\sim 60 \%$ mortality at $25^{\circ} \mathrm{C}$. Similar results were obtained at $30^{\circ} \mathrm{C}$, which clearly indicated that local DEs were more effective than SilicoSec ${ }^{\circledR}$ against maize weevil. The differences between imported and native DEs can be explained by the differences in physical, morphological and chemical characters of DEs. K1lıç and Mutlu (2020) [27] found the highest biological activity with local DE Aydın on Khapra larvae followed by Ankara DE, while SilicoSec ${ }^{\circledR}$ had the lowest activity at $30{ }^{\circ} \mathrm{C}$. However, Alkan et al., (2019) ${ }^{[2]}$ reported that local DE Turco000 caused $100 \%$ mortality of Acanthoscelides obtectus Say. adults on chickpea at 1000 ppm 4 DAT and can be used as a valuable tool in stored product pest management. Besides, complete mortality of $T$. confusum and $S$. oryzae can be achieved at lower concentrations ranging from 500 to $900 \mathrm{ppm}$ of local DE formulation (ACN-1) and this DE has potential to be used for control of stored-grain insects reported by Şen et al., (2019) [41].

The study showed that at least $600 \mathrm{ppm}$ dose all DEs at $30^{\circ} \mathrm{C}$ caused $>94 \%$ mortality on 2 DAT. The results of the present study indicated that complete mortality of cowpea beetle can only be achieved at higher concentrations, ranging from 400 to $600 \mathrm{ppm}$. These agree with Nabei et al., (2012) who reported mortality rates for $C$. maculatus were increased as the concentration of DE enhanced. Therefore, at higher concentrations, the adsorption of wax and abrasiveness occurs faster, causing death in a shorter time compared with low concentrations ${ }^{[42]}$. In addition, higher concentration of DEs can be the more effective, because dust applied to cover containers and grain surface will have greater chances of picking up by the insects and cause enough damage [30] (Masivii, 2004). Contrary to what is believed that bean grain surface is smooth, and adherence is lower than rough surface grain like wheat and maize, the result indicated that three DEs tested were very effective after 2 DAT on $C$. maculatus adults at $30{ }^{\circ} \mathrm{C}$.

There was no F1 adult emergence tested all DEs. The high mortality was observed for $25^{\circ} \mathrm{C}$ on 5 DAT and for $30^{\circ} \mathrm{C}$ on 2 DAT. These results could be due to the fact that high mortality rate of cowpea beetle might reduce the rate of oviposition and limit the survival of the insects and reduce the number of individuals in the progeny ${ }^{[47]}$. Our results agree with ${ }^{[2]}$ who reported that there was no progeny production with local DEs, Turco000, Turco004, Turco020 at 200 ppm concentration at the end of 55-days incubation period on $C$. maculatus.

The results presented in this study suggest that $600 \mathrm{ppm}$ dose of Ankara and Aydin DEs $30{ }^{\circ} \mathrm{C}$ temperatures can be recommended to control cowpea beetle with 3 days exposure time.

\section{Conclusions}

The two native diatomaceous earths obtained from local sources (Ankara and Aydin) and imported brand SilicoSec $\AA$ showed high efficacy against cowpea beetle under controlled conditions. The study also indicated that temperature had significant effect on the efficacy of a local DEs against the cowpea beetle. Based on the results of the bioassays, mortality increased with increasing dose and the exposure time. In conclusion local DEs (Ankara and Aydin) have high potential to be used for control of C. maculatus adults damage for storage bean.

\section{References}

1. Abbott WS. A method of computing the effectiveness of an insecticide. Journal of Economic Entomology. 1925; 18:265-267.

2. Alkan M, Erturk S, Firat TA, Ciftci E. Study of 
Insecticidal and Behavioral Effects and Some Characteristic of Native Diatomaceous Earth against the Bean Weevil, Acanthoscelides obtectus (Coleoptera: Chrysomelidae). Fresenius Environmental Bulletin. 2019; 28(4):2916-2922.

3. Anonymous. Plant Protection Technical Guide. General Directorate of Plant Protection, the Ministry of Agriculture and Rural Affair, Ankara. 2008; 1:206 -211 (in Turkish).

4. Arnaud L, Lang HTT, Brostaux Y, Haubruge E. Efficacy of diatomaceous earth formulations admixed with grain against populations of Tribolium castaneum. Journal of Stored Product Research. 2005; 41:121-130.

5. Arthur FH. Immediate and delayed mortality of Oryzaephilus surinamensis (L.) exposed on wheat treated with diatomaceous earth: effects of temperature, relative humidity, and exposure interval. Journal of Stored Product Research. 2001; 37:13-21.

6. Arthur FH. Survival of Sitophilus oryzae (L.) on wheat treated with diatomaceous earth: impact of biological and environmental parameters on product efficacy. Journal of Stored Product Research. 2002; 38:305-313.

7. Athanassiou, CG, Kavallieratos NG, Andris NS. Insecticidal effect of three Diatomaceous earth formulations against adults of Sitophilus oryzae (Coleoptera: Curculionidae) and Tribolium confusum (Coleoptera: Tenebrionidae) on oat, rye and triticale. Journal of Economic Entomology. 2004; 97:2160-2167.

8. Athanassiou CG, Vayias BJ, Dimizas CB, Kavallieratos NG, Papagregoriou AS, Buchelos C. Th. Insecticidal efficacy of diatomaceous earth against Sitophilus oryzae (L.) (Coleoptera: Curculionidae) and Tribolium confusum du Val (Coleoptera: Tenebrionidae) on stored wheat: influence of dose rate, temperature and exposure interval. Journal of Stored Products Research. 2005; 41:47-55.

9. Badii BK, Adarkwah C, Obeng-Ofori D, Ulrichs C. Efficacy of diatomaceous earth formulations against Callosobruchus maculatus (F.) (Coleoptera: Bruchidae) in Kersting's groundnut (Macrotyloma geocarpum Harms): influence of dosage rate and relative humidity. Journal of Pest Science. 2014; 87(2):285-294.

10. CABI. https://www.cabi.org/isc/datasheet/10987. (Accessing date: 12.10.2020)

11. Caswell GH. Damage to stored cowpea in the northern part of Nigeria. Samaru Journal of Agricultural Research. 1981; 1:11-19.

12. Çetin H, Uysal M, Şahbaz A, Alaoğlu Ö, Akgül A, Özcan M. Tıbbi ve aromatik bitki uçucu yağlarının fasulye tohum böceği (Acanthoscelides obtectus Say) (Coleoptera: Bruchidae) erginlerine fumigant etkileri. Selçuk Tarım ve Gıda Bilimleri Dergisi, 2014; 1(1):6-11.

13. Çetin M, Taş B. A natural mineral with biological origin: Diatomite. Turkish Science-Research Foundation Science Journal. 2012; 5(2):28-46.

14. Doumbia M, Douan GB, Kwadjo KE, Kra DK, Martel V, Dagnogo M. Effectiveness of diatomaceous earth for control of Sitophilus zeamais (Coleoptera: Curculionidae), Tribolium castaneum and Palorus subdepressus (Coleoptera: Tenebrionidae). Journal of Stored Products Research. 2014; 57:1-5.

15. Ebeling W. Sorptive dusts for pest control. Annual Review of Entomology. 1971; 16:123-158.

16. Eldridge MB. The effect of ingestion of diatomaceous earth in white rats: a subacute toxicity test. Toxicology and Applied Pharmacology.1964; 6:284-291.

17. Ertürk S, Emekçi M. Using possibilities of diatomaceous earth against stored paddy rice pest the red flour beetle Tribolium castaneum Herbst. Plant Protection Bulletin. 2014; 54(3):211-217.

18. Ferizli AG, Beris G. Mortality and F1 progeny of the lesser grain borer (Rhyzopertha dominica (F.)) on wheat treated with diatomaceous earth: Effects of dose, exposure interval and relative humidity. Pest Management Science. 2005; 61(11):1103-1109.

19. Fields P, Korunic Z. The effect of grain moisture content and temperature on the efficacy of diatomaceous earths from different geographical locations against storedproduct beetles. Journal of Stored Products Research. 2000; 36:1-13.

20. Foua-Bi K. Natural products use in the safeguarding of stocks in Black Africa. In: Thiam, A., Ducommun, G. (Eds.), Natural Protection of the Plants in Africa. EndaEditions, 1993, 85-100.

21. Golob P. Current status and future perspectives for inert dusts for control of stored product insects. Journal of Stored Products Research. 1997; 33:69-79.

22. Güdek M, Çetin H. Fumigant toxicity of Rosmarinus officinalis L. (Lamiales: Lamiaceae) essential oil against immature stages of Callosobruchus maculatus (Fabricius, 1775)(Coleoptera: Chrysomelidae). Turkish Journal of Entomology. 2016; 40(4):455-466.

23. Jackai LE, Daoust RA. Insect pests of cowpeas. Annual Review of Entomology. 1986; 31:95-119.

24. Işıkber AA, Özdamar HÜ, Karc1 A. Determination of insect species and their infestation rates on stored wheat in Kahramanmaraş and Adiyaman Province. KSU Journal of Science and Engineering. 2005; 8(1):107-113.

25. Kabir BGJ, Wulgo MA. Efficacy of four diatomaceous earth formulations against Callosobruchus maculatus (F.) (Coleoptera: Bruchidae) on cowpea. In Proc. 11th Int. Working Conf. Stored Prod. Protect. Chiang Mai, Thailand, 2014, 798-806.

26. Kavallieratos NG, Athanassiou CG, Vayias BJ, Maistrou S. Influence of temperature on susceptibility of Tribolium confusum (Coleoptera: Tenebrionidae) populations to three modified diatomaceous earth formulations. Florida Entomologist. 2007; 90:616-625.

27. Kılıç A, Mutlu Ç. Biological activity of some native diatomaceous earth against Khapra, Trogoderma granarium Everts (Coleoptera: Dermestidae), larvae under laboratory conditions. International Journal of Agricultural and Wildlife Sciences. 2020; 6(1):44-54.

28. Korunic Z. Rapid assessment of insecticidal value of diatomaceous earths without conducting bioassays. Journal of Stored Products Research.1997; 33:219-229.

29. Korunic Z. Diatomaceous earths, a group of natural insecticides. Journal of Stored Product Research. 1998; 34:87-97.

30. Masiiwa P. Evaluation of African Diatomaceous earths (DEs) As Potential Maize Grain Protectans Against the Maize Weevil (Sitophilus zeamais). Universty of Zimbabwe, Department of Crop Science, 2004, 41p.

31. Moravvej G, Hassanzadeh-Khayyat M, Abbar S. Vapor activity of essential oils extracted from fruit peels of two Citrus species against adults of Callosobruchus maculatus (Fabricius, 1775) (Coleoptera: Bruchidae). Turkish Journal of Entomology. 2010; 34(3):279-288.

32. Mucha-Pelzer T, Bauer R, Scobel E, Ulrichs C. 
Insecticidal Effects of Different Application Techniques for Silica Dusts in Plant Protection on Phaedon cochleariae Fab. and Pieris brassicae L. Hort Science. 2010; 45(9):1349-1356.

33. Nabaei N, Mehrvar A, Saber M, Bagheri M. Efficacy of entomopathogenic fungi in combination with diatomaceous earth against Callosobruchus maculatus (Coleoptera: Bruchidae). Acta Entomologica Sinica. 2012; 55(11):1282-1288.

34. Owusu OE. Effect of some Ghanaian plant components on control of two stored-product insect pests of cereals. Journal of Stored Product Research. 2001; 37:85-91.

35. Parsaeyan E, Saber M, Vojoudi S. Lethal and sublethal effects from short-term exposure of Callosobruchus maculatus (F.) (Coleoptera: Bruchidae) to diatomaceous earth and spinosad on glass surface. Acta Entomologica Sinica. 2012; 55(11):1289-1294.

36. Prasantha RBD, Reichmuth $\mathrm{CH}$, Buttner C. Effect of temperature and relative humidity on diatomaceous earth treated Callosobruchus maculatus and Acanthoscelides obtectus (Coleoptera: Bruchidae). $8^{\text {th }}$ International Working Conference on Stored Product Protection. 2002; 2:987-993.

37. Quarles W, Winn P. Diatomaceous Earth and Stored Product Pest. IPM Practitioner, 1996, 1-10.

38. Rigaux M, Haubruge E, Fields PG. Mechanisms for tolerance to diatomaceous earth between strains of Tribolium castaneum. Entomologia Experimentalis et Applicata. 2001; 101:33-39.

39. Rojht H, Horvat A, Athanassiou CG, Vayias BJ, Tomanović Z, Trdan S. Impact of geochemical composition of diatomaceous earth on its insecticidal activity against adults of Sitophilus oryzae (L.) (Coleoptera: Curculionidae). Journal of Pest Science. 2010; 83:429-436.

40. Selimoğlu T, Gökçe A, Yanar D. Fumigant toxicity of some plant essential oils to Acanthoscelides obtectus (Say) (Coleoptera: Bruchidae). Turkish Journal of Entomology. 2015; 39(1):109-118.

41. Şen R, Işikber AA, Bozkurt H and Sağlam Ö. Effect of temperature on insecticidal efficiency of local diatomaceous earth against stored-grain insects. Turkish Journal of Entomology. 2019; 43(4):441-450.

42. Shams G, Safaralizadeh MH, Imani S. Insecticidal effect of diatomaceous earth against Callosobruchus maculatus (F.) (Coleoptera: Bruchidae) and Sitophilus granarius (L.) (Coleoptera: Curculionidae) under laboratory conditions. African Journal of Agricultural Research. 2011; 6:5464-5468.

43. Sousa AH, Faroni LR, Andrade GS, Freitas RS, Pimentel MA. Bioactivity of diatomaceous earth to Sitophilus zeamais (Coleoptera: Curculionidae) in different application conditions. Revista Brasileira de Engenharia Agrícola e Ambiental. 2013; 17(9): 982-986.

44. Stathers TE, Denniff M, Golob P. The efficacy and persistence of diatomaceous earths admixed with commodity against four tropical stored product beetle pests. Journal of Stored Products Research. 2004; 40(1):113-123.

45. Subramanyam BH, Roesli R. Inert dusts (Eds. BH Subramanyam, DW Hagstrum). Alternatives to pesticides in stored product IPM. Kluwer Academic Publishers, Dordrecht, the Netherlands, 2000, 321-380p.

46. Turnbull SA, Harris CR. Influence of post treatment temperature on the contact toxicity of ten organophosphorus and pyrethroid insecticides to onion maggot adults (Diptera: Anthomyiidae). Proceedings of the Entomological Society of Ontario.1986; 117:41-44.

47. Vardeman EA, Arthur FH, Nechols JR, Campbell JF. Effect of temperature, exposure interval and depth of diatomaceous earth on distribution, mortality, and reproduction of the lesser grain borer, Rhyzopertha dominica (F.) (Coleoptera: Bostrichidae) in stored wheat. Journal of Economic Entomology. 2006; 99:1017-1024.

48. Vassilakos TN, Athanassiou CG, Kavallieratos NG, Vayias BJ. Influence of temperature on the insecticidal effect of Beauveria bassiana in combination with diatomaceous earth against Rhyzopertha dominica and Sitophilus oryzae on stored wheat. Biological Control. 2006; 38(2):270-281.

49. Vayias BJ, Athanassiou CG, Kavallieratos NG, Buchelos CTH. Susceptibility of different European Populations of Tribolium confusum (Coleoptera: Tenebrionidae) to five diatomaceous earth formulations. Journal of Economic Entomolology. 2006; 99:1899-1904.

50. Wakil W, Ghazanfar MU, Yasin M, Jung Kwon Y. Efficacy of Metarhizium anisopliae combined with diatomaceous earth against Sitophilus oryzae (Coleoptera: Curculionidae) under laboratory conditions. Revista Colombiana de Entomología. 2015; 41(1):81-86. 